IZA DP No. 3593

Services Offshoring and Wages:

Evidence from Micro Data

Ingo Geishecker

Holger Görg

J uly 2008 


\title{
Services Offshoring and Wages: Evidence from Micro Data
}

\author{
Ingo Geishecker \\ University of Göttingen \\ and Aarhus Business School \\ Holger Görg \\ IfW and CAU Kiel, \\ GEP Nottingham, CEPR and IZA
}
Discussion Paper No. 3593
July 2008

IZA

P.O. Box 7240

53072 Bonn

Germany

Phone: +49-228-3894-0

Fax: +49-228-3894-180

E-mail: iza@iza.org

\begin{abstract}
Any opinions expressed here are those of the author(s) and not those of IZA. Research published in this series may include views on policy, but the institute itself takes no institutional policy positions.

The Institute for the Study of Labor (IZA) in Bonn is a local and virtual international research center and a place of communication between science, politics and business. IZA is an independent nonprofit organization supported by Deutsche Post World Net. The center is associated with the University of Bonn and offers a stimulating research environment through its international network, workshops and conferences, data service, project support, research visits and doctoral program. IZA engages in (i) original and internationally competitive research in all fields of labor economics, (ii) development of policy concepts, and (iii) dissemination of research results and concepts to the interested public.
\end{abstract}

IZA Discussion Papers often represent preliminary work and are circulated to encourage discussion. Citation of such a paper should account for its provisional character. A revised version may be available directly from the author. 
IZA Discussion Paper No. 3593

July 2008

\section{ABSTRACT}

\section{Services Offshoring and Wages: Evidence from Micro Data}

This paper investigates the effects of services offshoring on wages using individual level data combined with industry information on offshoring. Our results show that services offshoring affects the real wage of low and medium skilled individuals negatively. By contrast, skilled workers benefit from services offshoring in terms of higher real wages. Hence, offshoring has contributed to a widening of the wage gap between skilled and less skilled workers. This result is obtained while controlling for individual and sectoral observed and unobserved heterogeneity. In particular, our empirical model also controls for the impact of technological change and offshoring of materials.

JEL Classification: F16, J31, C23

Keywords: $\quad$ services offshoring, individual wages

Corresponding author:

Holger Görg

Institut für Weltwirtschaft

Düsternbrooker Weg 120

D-24105 Kiel

Germany

E-mail: holger.goerg@ifw-kiel.de 


\section{Introduction}

Offshoring of services activities from industrialised countries, and the resulting impact on domestic labour markets, is a topical issue, both in academic discourse and public debate. In a recent study, Blinder (2007) looks carefully at characteristics of occupations with a view to their potential offshorability. Based on his data he estimates that around 25 per cent of all US jobs can potentially be relocated to other countries, as they do not involve much personal contact. It is, of course, important to keep in mind that he only comes up with the number of jobs that are potentially offshorable, while he does not give any estimate as to the number of jobs that may actually be relocated in the future. Thinking more about the actual number of jobs, several scholars have investigated the impact of offshoring on actual employment levels or growth. For the US, for example, Amiti and Wei (2007) estimate industry level labour demand equations for US industries where they use actual offshoring of services as an explanatory variable. They find little evidence of reductions in employment following increased levels of services offshoring.

The US is, of course, not the only country where offshoring is hotly debated. Many observers in Europe also join in the discussion. Here, the UK is particularly prominent, perhaps because the trend to offshore services has started earlier than in many continental European countries. Still, evidence on labour market effects of such offshoring activities is scant. Amiti and Wei (2005), similar to their study for the US, conclude that there have been little effects of offshoring on employment. Their analysis is based on estimating labour demand equations using industry data for the UK. Using highly disaggregated firm level data on job creation and destruction, and firm level data on trade in services, Hijzen et al. (2007) also fail to find any negative effects of services offshoring (measured as services imports). By contrast, they find that, on average, firms that start offshoring services experience faster employment growth than other comparable firms.

Hence, the conclusion that may be drawn from the work so far is that there is little to worry about for domestic workers, although, the literature thus far focuses on the quantity of labour not at the price. However, standard theory reminds us that an adjustment in the labour market to offshoring can go through either quantity or the price of labour, or both. In this case, concluding on the benevolent (or otherwise) effects of offshoring purely on the basis of an analysis of the quantity of labour can be misleading. Especially in a country 
with flexible labour markets such as the US or the UK a full labour market picture of the effects of offshoring of services needs to look at the price of work as well. This is the gap we fill in this paper.

We investigate the effect of offshoring of services activities on individual workers wages. To do so, we use household level panel data from the British Household Panel Survey (BHPS) and combine these with industry level measures of offshoring of services inputs over the period 1992 to 2004 . Hence, our approach allows us to estimate the effect of increasing offshoring activities in an industry on individual wages of workers working in the affected industry. To identify the effects, we allow for observed and unobserved worker level heterogeneity, using the detailed information provided in the household panel data, and also control for technological change, and offshoring of tangible (material) inputs in the industry. ${ }^{1}$

The paper makes a number of contributions to the literature. It is the first analysis we are aware of that looks at the wage effects of services offshoring using individual level data. This is a highly policy relevant issue and deserves of detailed inspection. The use of household panel data allows us to control for observed and unobserved heterogeneity, avoiding aggregation bias that may hamper more aggregate studies. Also, it allows to clearly identify the winners and losers from this form of globalisation. Second, the combination of household level data for wages and industry level data for services offshoring mitigates concerns about the possible endogeneity of offshoring. However, we explicitly test for the exogeneity of our services offshoring variable. A third contribution of our paper lies in the utilisation of data from the United Kingdom, where offshoring of services has attracted much attention in the academic literature and the popular debate. It is also a country with relatively flexible labour markets where much of the adjustment in labour to the process of offshoring may be expected through the price of labour, and not just through the quantity.

Our results show that services offshoring affects the real wage of low and medium skilled individuals negatively. By contrast, skilled workers benefit from services offshoring in terms of higher real wages. Hence, offshoring has contributed to a widening of the wage gap between skilled and less skilled workers. This result is obtained while controlling for individual and sectoral observed and unobserved heterogeneity. In particular, our empirical model also

\footnotetext{
${ }^{1}$ These variables have been shown to affect the relative wages of skilled workers, see, e.g., Feenstra and Hanson (1999), Hijzen et al. (2005).
} 
controls for the impact of technological change and offshoring of materials.

The remainder of the paper is structured as follows. Section 2 introduces the data on offshoring of both services and materials. Section 3 discusses the empirical methodology and Section 4 presents the results. Some concluding remarks are in Section 5.

\section{Service offshoring in the UK}

The measurement of offshoring, either services or materials is not straightforward and is greatly limited by data availability of coherent and comparable (across sectors and or countries) information on such activities. Hence, trade economists usually revert to measuring trade in intermediates as a proxy. We follow this approach here. Still, data on trade in intermediates are also difficult to come by. Amiti and Wei (2007) calculate trade in intermediates by measuring the importance of intermediates in a sector using data from input-output tables and combine it with data on imports (which do not distinguish final and intermediate goods) from official trade statistics. ${ }^{2}$ They cannot observe the actual proportion of imported inputs. The implicit assumption in this definition is that imports are used as inputs in the same proportion as domestic inputs. This, however, could be problematic if, e.g., an industry uses different types of inputs from domestic and foreign sources. Our definition of offshoring is a more direct measure of imported services inputs. Specifically, we derive data on imported services inputs directly from national accounts' input-output supply tables provided by UK National Statistics for the years 1992 to $2004 .^{3}$

Formally service offshoring is defined as:

$$
O S S_{i t}=\frac{I S_{i^{*} t}}{Y_{i t}}
$$

with $I S_{i t}$ denoting all imported services and $Y$ representing the production value of industry $i$ in period $t$. Information on both $I S$ and $Y$ is directly observable in the supply and use tables. ${ }^{4}$

For materials offshoring we have to also draw on international trade data as the available

\footnotetext{
${ }^{2}$ This follows the definition of materials offshoring used by Feenstra and Hanson (1999).

${ }^{3}$ UK National Statistics, Input-Output, Supply and Use Tables, August 2006.

${ }^{4}$ It would be interesting to investigate to which countries services are offshored. However, this is not possible to determine with the data from the supply and use tables.
} 
detailed input-output use tables do not differentiate between imported and domestically supplied materials. ${ }^{5}$ Thus, we look at aggregate imports of manufactured goods and allocate them according to their use share in domestic industries based on aggregate input-output use tables. Conceptionally, our materials offshoring measure is therefore in line with the narrow outsourcing measure in Feenstra and Hanson (1999).

More formally, material offshoring is defined as:

$$
O S M_{i t}=\frac{I M P_{i^{*} t} \times \Omega_{i i^{*} t}}{Y_{i t}}
$$

with $I M P_{i^{*} t}$ denoting imported intermediate inputs from the same respective foreign industry $i^{*}$. $\Omega_{i i^{*} t}$ denotes the share of domestic and foreign inputs from a industry $i$ that are consumed in industry $i .^{6}$

Figure 1 looks at the development of the two offshoring measures over time as a manufacturing average. What is noteworthy is the tremendous increase in services offshoring since the late 1990's. By contrast, although materials offshoring has grown steadily since the early 1990's its overall growth rate is approximately only slightly above half of that for service offshoring ( 37 vs. 67 percent). ${ }^{7}$

Table 1 presents some summary statistics on the measures of services and materials offshoring for our particular BHPS sample used in the econometric analysis below, which takes the industrial composition of our micro data into account. The average intensity of offshoring materials is 5.0 percent, while that of services offshoring is 2.6 percent. There is a fairly high standard deviation around this mean, which is due not only to variation between but also within industries. In other words, offshoring ratios in industries show considerable variation over time, which can be exploited in the econometric analysis below.

\section{Methodology and data}

To assess the impact of offshoring activity in an industry on individual wages we estimate simple Mincer human capital wage equations of the form

\footnotetext{
${ }^{5}$ This is a common problem, e.g. US input output tables suffer from the same shortcoming.

${ }^{6}$ Note that $\sum_{i=1}^{I} \Omega_{i i^{*} t}=1$ only if industries $I$ contains agriculture, services, private and public consumption, inventories, capital formation and exports.

${ }^{7}$ These figures for services offshoring and its upward trend are broadly in line with Amiti and Wei (2005).
} 


$$
\log w_{i j t}=\alpha+\beta X_{i t}+\gamma Y_{j t}+\lambda_{S} O S S_{j t}+\lambda_{M} O S M_{j t}+T_{j}+\mu_{t}+\alpha_{i}+\iota_{j}+\epsilon_{i j t},
$$

where $w_{i j t}$ is the hourly wage of worker $i$ in industry $j$ at time $t$, defined as average hourly gross labour earnings including bonuses, premia and other extra payments over the year preceding the respective interview month. $X_{i t}$ is a vector of standard demographic and human capital variables which includes age, age squared, dummies for the presence of children and being married, job tenure, tenure squared, an indicator variable for high education, dummies for occupation using the nine main categories of the ISCO code, dummies for firm size and regional dummies. Year effects, $\mu_{t}$, and individual specific fixed effects, $\alpha_{i}$, are also controlled for. In addition we include industry dummies $\iota_{j}$, and to control for time varying industry characteristics we also enter industry output, $Y_{j t}$, the ratio of industry level $\mathrm{R} \& \mathrm{D}$ to output, and industry specific time trends $T_{j}$ in the model. The inclusion of R\&D and industry specific time trends controls for industry specific technological progress. The main explanatory variable of interest, of course, are the variables for services and material offshoring, $O S S_{j t}$ and $O S M_{j t}$.

All the regressions are weighted using the standard sampling weights from the household data to adjust for individual sampling probabilities. Finally a methodological point should be mentioned. In the wage equation (1) we estimate the effect of an aggregate variable (i.e. outsourcing at the industry level) on wages of individual workers, so the standard errors of the estimated coefficients may be biased downwards as indicated in Moulton (1990). Accordingly, we adjust standard errors allowing for contemporaneous correlation within two digit industries as has become standard in the literature.

We measure wages and worker characteristics using individual level data from the British household panel survey (BHPS) for the period 1992 - 2004. The annual survey, which started in 1991, is based on a nationally representative sample of households. Individuals are followed over time. The database provides data on wages and education levels, as well as many individual characteristics which are included in our empirical model to control for observed individual level heterogeneity. Table2 provides descriptive statistics for our explanatory variables. In the estimation, we restrict our sample to male prime age individuals (i.e., 18 to 65 year old) working in manufacturing. 
Our unbalanced sample covers 997 individuals yielding 5775 observations. In order to avoid selection bias with respect to item non-response that might be non-random each explanatory variable was supplemented with a dummy for missing values. Subsequently, missing values where recoded to zero and the generated dummies for missing values also act as regressors in the model.

A particular focus of our analysis lies on skill specific effects of offshoring. We follow the International Standard Classification of Education (ISCED) and differentiate between highskilled workers $(E D: H i g h)$, medium-skilled workers $(E D: M e d)$ and low-skilled workers (ED : low) according to the grouping presented in Table 3. To estimate skill specific effects we interact the offshoring variables with dummies for the three skill categories.

Figure 2 provides some evidence on the development of the median wage rate and the 10th and 90th percentile for the three different skill groups between 1992 to 2004 . Note that wages for all three groups increased over time. The trends for all three skill groups have been fairly consistent over time. In particular, they do not show any obvious break since the late 1990s when services offshoring increased. Of course, this simple eye balling of the graphs does not control for other factors impacting on wages. Hence, in order to check more formally whether offshoring affects wages we now turn to estimating equation (1) in the next section.

\section{Estimation results}

Table 4 presents the regression results. Inspection of column (1) shows that services offshoring has a negative and statistically significant effect on individual level wages. In other words, workers in industries with increasing levels of services offshoring are likely to experience reductions in their wage, conditional on all variables included in the model. The magnitude of the coefficient suggests that a one percentage point increase in the services offshoring intensity of the industry leads to a 0.7 per cent reduction in real wages.

Column (2) shows results which also include the intensity of material offshoring in the industry. This is included for two reasons. First, it allows us to see whether the estimated coefficient is robust to this inclusion in that it does not just reflect an industry's propensity to offshore in general. Second, it also enables us to distinguish the relative magnitude of services and material offshoring for wage changes. The results show that, firstly, the coefficient on 
services offshoring is indeed robust; it does not change much in either statistical significance or magnitude. Comparing the estimate with the coefficient for material offshoring shows that the marginal effect of services offshoring is roughly similar to that of materials offshoring. Increases by one per centage point in both types is associated with decreases in real wages of just under one per cent. ${ }^{8}$

Of course, the estimations thus far assume that the effect of offshoring on wages is the same across education groups. This is unlikely to be a reasonable assumption. If industries offshore mainly low skilled services and material activities abroad, then we may expect a negative effect on unskilled workers but not on high skilled workers. ${ }^{9}$ In order to investigate this we, in column (3) report results of an estimation in which we interact the two offshoring variables with dummy variables for individuals in three different skill groups, namely, low, medium and high skilled. As the results show, the negative coefficients of services offshoring are statistically significant only for low and medium skilled workers. For material offshoring, we also find that wages for these two types of workers are statistically significantly negatively affected. This suggests that industries offshore low to medium skilled manufacturing and services activities. As for high skilled workers, we find that their wages are positive associated with increased services offshoring, but not with material offshoring.

A noteworthy aspect of this regression is that the coefficient on material and services offshoring for low and medium skilled workers are quite similar. In fact, testing the equality of coefficients does not allow us to reject the null that they are equal. ${ }^{10}$ Hence, the marginal effects of the two types of offshoring are similar for low skilled individuals. Furthermore, we cannot reject the hypothesis that the coefficient on services offshoring is the same for low and medium skilled workers, ${ }^{11}$ although the marginal effect of materials offshoring is different for these two types of workers. ${ }^{12}$

An important assumption implicit in our estimation thus far is that of exogeneity of regressors. This may be questionable in particular with respect to the offshoring variables. These may be endogenous due to reverse causality - industries with unskill intensive produc-

\footnotetext{
${ }^{8}$ We cannot reject the null hypothesis that the two coefficients are equal.

${ }^{9}$ To be precise, we would expect a decrease in the relative wage of unskilled workers on the basis of a simple modification of a Heckscher-Ohlin model which accommodates trade in intermediates (e.g., Feenstra and Hanson, 1999). Whether or not the real wage of unskilled workers also falls is not clear in such a set up. However, it is still reasonable to assume that the effects on real wages are different for the two skill groups.

${ }^{10} \mathrm{~F}$ test, p-value of 0.203 and 0.473 , respectively for medium and low skilled workers.

${ }^{11} \mathrm{~F}$ test, $\mathrm{p}$-value of 0.451 .

${ }^{12} \mathrm{~F}$ test, p-value of 0.017 .
} 
tion (and low wages for unskilled workers) may also be those that are more likely to offshore. In this case our conclusions based on the estimations thus far would be problematic. We have three responses to this concern. First, given that there is substantial heterogeneity in individual wages the described scenario, that variation in individual wages causes industry level offshoring, is unlikely. Second, we control for industry level fixed effects which would control for time invariant characteristics, such as production technology, of the different industries. Third, we explicitly tested the assumption of exogeneity of the offshoring variables using a C-test, based on a re-estimation of the equations in columns (1) to (3) using an instrumental variable GMM approach. The endogenous variables are the respective offshoring variables and excluded instruments are their lags, lags of total services offshoring as well as the lag of a "wide" definition of materials offshoring. ${ }^{13}$ The test statistics are reported at the bottom of Table 4. They show that we cannot reject the null hypothesis of instrument validity (Hansen J statistic). Neither can we reject the assumption of exogeneity of the variables in question from the $\mathrm{C}$ test.

To judge the economic significance of our estimates we engage in a thought experiment of implied wage changes. Table 5 reports the median hourly wages for the three skill groups in 1992, the beginning of our sample period. We also report the coefficients from the estimation of the preferred specification in column (6) of Table 4. Over the full sample period, services offshoring increased by 1.57 percentage points, while the increase for materials offshoring was at 0.46 percentage points. For a worker with the average number of working hours (1,732 per year for the UK, see OECD, 2008) this implies that the cumulative increase in wages due to offshoring for high skilled workers was GBP 1,152, and this is entirely due to offshoring of services inputs. For low skilled workers, the equivalent reduction in wages was GBP 253, GBP 176 of which were due to services offshoring and the remainder due to materials offshoring. Given that these are effects of cumulative changes of offshoring over a ten year period these numbers are small, but not so small as to be neglected. It also shows that, even though regression coefficients are similar, the economic implications of services offshoring on wages have been much stronger than those of material offshoring. ${ }^{14}$

\footnotetext{
${ }^{13}$ Wide offshoring is defined by Feenstra and Hanson (1999). It captures intermediate material inputs that are imported from other industries than the own industry.

${ }^{14} \mathrm{~A}$ potential question regarding our estimations is how robust this is to the definition of skills we use. As an alternative, we use a skill definition based on occupations, information on which is in the BHPS. We classify individuals into high, medium and low skilled occupations. The results based on this approach are comparable to the estimates reported here in terms of signs, statistical significance and magnitude for low and medium skilled workers. One notable difference is that we now do not find any statistically significant
} 


\section{Conclusion}

This paper looks at the relationship between offshoring of services and individual workers wages, using household level panel data from the British Household Panel Survey (BHPS) combined with industry level measures of offshoring of services activities over the period 1992 to 2004. Our results show that services offshoring affects the real wage of low and medium skilled individuals negatively. By contrast, skilled workers benefit from services offshoring in terms of higher real wages. Hence, offshoring has contributed to a widening of the wage gap between skilled and less skilled workers. However, looking at the magnitude of these effects we find that they are rather small, but not so small as to be negligible. Hence, we have identified winners and losers in terms of wage gains from services offshoring. The policy relevant question is now whether the losers should be compensated and, if this is answered in the affirmative, what form such a compensation should have. Another policy implication is that skill upgrading needs to be continued in order to allow unskilled workers to move into the "winning" category of skilled work.

effect of services offshoring on high skilled workers. However, the main message still holds: services offshoring affects low and medium skilled workers differently than high skilled workers, and the economic significance of services offshoring is much higher than that of materials offshoring. Results are not reported here to save space, but can be obtained upon request. 


\section{References}

[1] Amiti, M. and S.J. Wei (2005), Fear of service outsourcing: Is it justified?, Economic Policy 20, 308-347

[2] Amiti, M. and S.J. Wei (2007), Service offshoring, productivity and employment: Evidence from the US, CEPR Discussion Paper 5475

[3] Blinder, A.S. (2007), How many U.S. jobs might be offshorable? CEPS Working Paper 142, Princeton University

[4] Feenstra, R.C. and G.H. Hanson (1999), The impact of outsourcing and high-technology capital on wages: Estimates for the United States, 1979-1990, Quarterly Journal of Economics 114, 907-941

[5] Hijzen, A., H. Görg and R.C. Hine (2005), International outsourcing and the skill structure of labour demand in the United Kingdom, Economic Journal 115, 860-878

[6] Hijzen, A., M. Pisu, R. Upward and P. Wright (2007), Employment, job turnover, and the trade in producer services: firm-level evidence, GEP Research Paper 2007/37, University of Nottingham

[7] OECD (2008), Factbook, Paris: OECD 


\section{Tables and figures}

Figure 1: Service and Materials Offshoring, Manufacturing Average

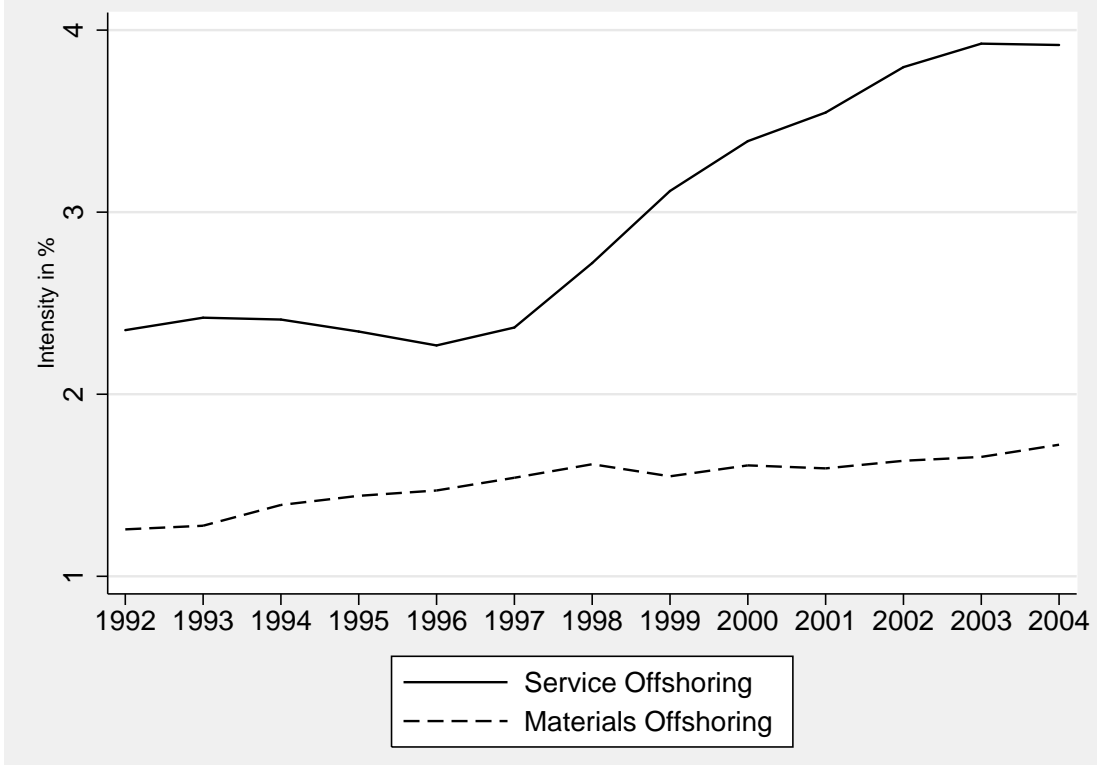

Note: Authors calculations.

Figure 2: Wages by skill

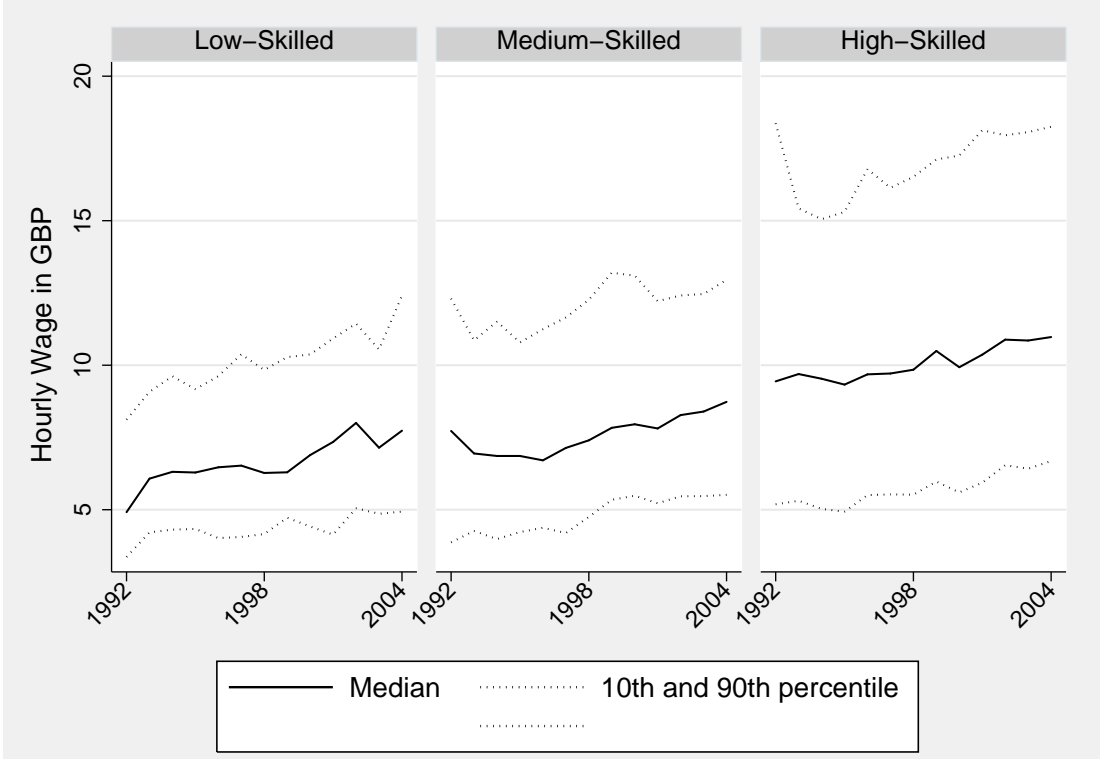

Note: Authors calculations. 
Table 1: Offshoring within sample

\begin{tabular}{|c|c|c|c|c|}
\hline & & Mean & $\begin{array}{l}\text { Standard } \\
\text { Deviation }\end{array}$ & \\
\hline OSS & $\begin{array}{l}\text { overall } \\
\text { between } \\
\text { within }\end{array}$ & 2.5545 & $\begin{array}{l}3.2791 \\
2.9283 \\
1.6070\end{array}$ & \\
\hline OSM & $\begin{array}{l}\text { overall } \\
\text { between } \\
\text { within }\end{array}$ & 4.9043 & $\begin{array}{l}3.3855 \\
2.8385 \\
1.9771\end{array}$ & $\begin{array}{l}\mathrm{N}=5775 \\
\mathrm{n}=997\end{array}$ \\
\hline
\end{tabular}

Table 2: Summary Statistics

\begin{tabular}{|c|c|c|}
\hline & Mean & Standard Deviation \\
\hline Hourly Wage & 9.12 & 5.20 \\
\hline Age $: 18-25$ & 0.11 & 0.32 \\
\hline Age $: 26-35$ & 0.26 & 0.44 \\
\hline Age $: 36-50$ & 0.43 & 0.49 \\
\hline Married: Dummy & 0.65 & 0.48 \\
\hline Children : Dummy & 0.45 & 0.50 \\
\hline Tenure & 214.99 & 107.52 \\
\hline Tenure ${ }^{2}$ & 57776.74 & 54080.26 \\
\hline Tenure : noresponse & 0.10 & 0.30 \\
\hline ISCED: high & 0.43 & 0.49 \\
\hline ISCED: med & 0.34 & 0.47 \\
\hline FirmSize $:<25$ & 0.18 & 0.39 \\
\hline FirmSize : $25-100$ & 0.22 & 0.42 \\
\hline FirmSize : $100-1000$ & 0.47 & 0.50 \\
\hline Firm : public & 0.00 & 0.06 \\
\hline Firm : unknownowner & 0.00 & 0.01 \\
\hline Industry : Output & 29.14 & 16.62 \\
\hline Industry $: R \& D / Y$ & 2.36 & 2.81 \\
\hline
\end{tabular}

Table 3: Skill Grouping

\begin{tabular}{ll}
\hline High-Skilled & Second stage of tertiary education \\
Medium-Skilled & $\begin{array}{l}\text { Upper-secondary education } \\
\text { Post-secondary but non-tertiary education } \\
\text { First stage of tertiary education }\end{array}$ \\
& $\begin{array}{l}\text { Pre-primary education } \\
\text { Primary education } \\
\text { Lower-secondary education }\end{array}$ \\
\hline
\end{tabular}


Table 4: Regression Results

\begin{tabular}{|c|c|c|c|}
\hline & $\mathrm{I}$ & II & III \\
\hline Age $: 18-25$ & $\begin{array}{l}-0.0506 \\
{[1.33]}\end{array}$ & $\begin{array}{l}-0.0492 \\
{[1.29]}\end{array}$ & $\begin{array}{l}-0.0481 \\
{[1.24]}\end{array}$ \\
\hline Age : $26-35$ & $\begin{array}{l}0.0414 \\
{[1.24]}\end{array}$ & $\begin{array}{l}0.0423 \\
{[1.26]}\end{array}$ & $\begin{array}{l}0.0407 \\
{[1.21]}\end{array}$ \\
\hline Age: $36-50$ & $\begin{array}{l}0.0531 \\
{[2.01]^{*}}\end{array}$ & $\begin{array}{l}0.0534 \\
{[2.03]^{*}}\end{array}$ & $\begin{array}{l}0.0538 \\
{[2.03]^{*}}\end{array}$ \\
\hline Married : Dummy & $\begin{array}{l}0.0241 \\
{[1.08]}\end{array}$ & $\begin{array}{l}0.0245 \\
{[1.10]}\end{array}$ & $\begin{array}{l}0.0242 \\
{[1.11]}\end{array}$ \\
\hline Children : Dummy & $\begin{array}{l}0.0273 \\
{[2.21]^{* *}}\end{array}$ & $\begin{array}{l}0.0274 \\
{[2.23]^{* *}}\end{array}$ & $\begin{array}{l}0.0261 \\
{[2.15]^{* *}}\end{array}$ \\
\hline Tenure & $\begin{array}{l}0.0008 \\
{[3.10]^{* * *}}\end{array}$ & $\begin{array}{l}0.0008 \\
{[3.12]^{* * *}}\end{array}$ & $\begin{array}{l}0.0008 \\
{[2.91]^{* *}}\end{array}$ \\
\hline Tenure ${ }^{2}$ & 0 & 0 & 0 \\
\hline Tenure: noresponse & $\begin{array}{l}0.1307 \\
{[3.36]^{* * *}}\end{array}$ & $\begin{array}{l}0.1316 \\
{[3.37]^{* * *}}\end{array}$ & $\begin{array}{l}0.129 \\
{[3.24]^{* * *}}\end{array}$ \\
\hline ISCED: high & $\begin{array}{l}-0.0224 \\
{[0.74]}\end{array}$ & $\begin{array}{l}-0.0225 \\
{[0.74]}\end{array}$ & $\begin{array}{l}-0.0702 \\
{[1.66]}\end{array}$ \\
\hline ISCED: med & $\begin{array}{l}-0.006 \\
{[0.16]}\end{array}$ & $\begin{array}{l}{[0.0056} \\
-0.005]\end{array}$ & $\begin{array}{l}{[1.00]} \\
-0.0524 \\
{[1.09]}\end{array}$ \\
\hline FirmSize $:<25$ & $\begin{array}{l}-0.0754 \\
{[2.80]^{* *}}\end{array}$ & $\begin{array}{l}-0.0757 \\
{[2.85]^{* *}}\end{array}$ & $\begin{array}{l}-0.0769 \\
{[2.88]^{* *}}\end{array}$ \\
\hline FirmSize: $25-100$ & -0.0378 & -0.0381 & $\begin{array}{l}-0.0384 \\
{[1.88]^{*}}\end{array}$ \\
\hline FirmSize $: 100-1000$ & -0.0031 & -0.0033 & $\begin{array}{l}-0.0041 \\
{[0.20]}\end{array}$ \\
\hline Firm : public & $\begin{array}{l}{[.10]} \\
0.0724 \\
{[0.89]}\end{array}$ & $\begin{array}{l}{[0.0737} \\
0.91]\end{array}$ & $\begin{array}{l}{[0.0719} \\
0.87]\end{array}$ \\
\hline Firm: unknownowner & $\begin{array}{l}-0.1061 \\
{[6.21] * * *}\end{array}$ & $\begin{array}{l}-0.1013 \\
{[6.44]^{* * *}}\end{array}$ & -0.1174 \\
\hline Industry: Output & $\begin{array}{l}{[0.21]} \\
0.87]\end{array}$ & $\begin{array}{l}{[0.0133} \\
0.013\end{array}$ & $\begin{array}{l}{[.41]} \\
0.0133 \\
{[1.33]}\end{array}$ \\
\hline Industry : $R \& D / Y$ & $\begin{array}{l}-0.0108 \\
{[1.66]}\end{array}$ & $\begin{array}{l}-0.0066 \\
{[0.92]}\end{array}$ & $\begin{array}{l}-0.0123 \\
{[1.89]^{*}}\end{array}$ \\
\hline OSS & $\begin{array}{l}-0.0074 \\
{[2.12]^{* *}}\end{array}$ & $\begin{array}{l}-0.0097 \\
{[2.96]^{* * *}}\end{array}$ & \\
\hline$O S S \times I S C E D: h i g h$ & & & $\begin{array}{l}0.045 \\
{[2.65]^{* *}}\end{array}$ \\
\hline$O S S \times I S C E D:$ med & & & -0.0114 \\
\hline$O S S \times I S C E D:$ low & & & -0.0132 \\
\hline$O S M E$ & & $\begin{array}{l}-0.0088 \\
{[2.09]^{*}}\end{array}$ & \\
\hline$O S M \times I S C E D: h i g h$ & & & $\begin{array}{l}-0.0027 \\
{[0.66]}\end{array}$ \\
\hline$O S M \times I S C E D:$ med & & & -0.0085 \\
\hline$O S M \times I S C E D:$ low & & & $\begin{array}{l}-0.0195 \\
{[4.43]^{* * *}}\end{array}$ \\
\hline Constant & $\begin{array}{l}1.167 \\
{[1.77]^{*}}\end{array}$ & $\begin{array}{l}0.9738 \\
{[1.57]}\end{array}$ & $\begin{array}{l}1.0105 \\
{[1.68]}\end{array}$ \\
\hline Observations & 5775 & 5775 & 5775 \\
\hline$R^{2}$ & 0.82 & 0.82 & 0.83 \\
\hline Occupation $C$ & YES & YES & YES \\
\hline fects & YES & YES & YES \\
\hline Region Dummies & YES & YES & YES \\
\hline Industry Dummies & YES & YES & YES \\
\hline Industry Specific Time Trends & YES & YES & YES \\
\hline \multicolumn{4}{|l|}{ Exogeneity Test } \\
\hline $\mathrm{C}-\mathrm{S}$ & 0.509 & 2.887 & \\
\hline
\end{tabular}

Note: t-statistics in brackets, ${ }^{* * *}$ significant at $1 \%,{ }^{* *}$ at $5 \%, *$ at $10 \%$. Default categories: Age :> 50, ISCED:low, FirmSize :> 1000. 
Table 5: Cumulated wage effects of increased offshoring, at 1992 median wages

\begin{tabular}{|c|c|c|c|}
\hline & High-Skilled & Medium-Skilled & Low-Skilled \\
\hline \multicolumn{4}{|c|}{ Median hourly wage (1992) } \\
\hline & 9.44 & & 4.92 \\
\hline \multicolumn{4}{|c|}{ Coefficient, Table 4, Column III } \\
\hline & 0.05 & -0.01 & -0.01 \\
\hline OSM & 0.00 & -0.01 & -0.02 \\
\hline \multicolumn{4}{|c|}{$\begin{array}{c}\text { Percentage Point Change, 1992-2004 } \\
\text { OSS }=1.57 \\
\text { OSM }=0.46\end{array}$} \\
\hline \multicolumn{4}{|c|}{ Cumulated yearly wage change in GBP ( 1732 work hours) } \\
\hline OSS & 1152.51 & -238.91 & -176.02 \\
\hline OSM & 0.00 & -52.88 & -77.19 \\
\hline OSS+OSM & 1152.51 & -291.78 & -253.21 \\
\hline
\end{tabular}

Note: assumed 1732 annual work hours in 1992 according to OECD (2008, Factbook) 